\title{
Bispecific Antibodies: Bright Way for Cancer Therapeutics
}

\section{Junpeng Qi ${ }^{*}$}

Department of Cancer Biology, The Scripps Research Institute, Jupiter, Florida, USA

“Corresponding author: Junpeng Qi, Department of Cancer Biology, The Scripps Research Institute, Jupiter, Florida, USA, Tel: 561-228-2000; E-mail: jqi@scripps.edu

Received date: October 28, 2016; Accepted date: November 04, 2016; Published date: November 07, 2016

Copyright: ( 2016 Junpeng Qi. This is an open-access article distributed under the terms of the Creative Commons Attribution License, which permits unrestricted use, distribution, and reproduction in any medium, provided the original author and source are credited.

Citation: Junpeng Qi (2016) Bispecific Antibodies: Bright way for Cancer Therapeutics. J Immuno Biol 1: e103.

Citation: Qi J (2016) Bispecific Antibodies: Bright Way for Cancer Therapeutics. J Immuno Biol 1: e103. doi:10.4172/2476-1966.1000e103

\section{Editorial}

Antibody based cancer therapeutics show great beneficial to more and more patients and the antibody drug market is growing fast. As Removab $^{\circ}$ approved in 2009 and Blincyto ${ }^{\mathrm{TM}}$ approved in 2014, bispecific antibodies with combination of two antigen binding specificities shed new light on antibody based cancer therapeutics especially when new technologies for engineering and manufacturing are available.

Currently, most of approved antibody for cancer therapy is monospecific with limited binding to one antigen. Drug resistance and cancer relapsed are the biggest obstacle for monoclonal antibody $(\mathrm{mAb})$ therapy $[1,2]$. Bispecific antibodies with two functional "arms" simultaneously addressing two different antigens or epitopes are sufficient to target two pathways involved in cancer pathogenesis showing advantage over the mAb therapy (for example, targeting EGFR and IGFR) [3]. With the combination of specificity of two different antibodies, bispecific antibodies have inherent specificity towards target. Moreover, some clinical studies have shown that the expression level of targeted receptor is decreased or even lost after $\mathrm{mAb}$ therapy, such as anti-CD20 therapeutics [4-6]. Bispecific antibodies could be worthwhile to try to push CD20 targeting therapy back to the right path.

The major advantage of bispecific antibodies is harnessing immune effector cells to kill cancer cells. Cytotoxic T lymphocytes play a critical role in immunosurveillance and anti-cancer immunity. Bispecific antibodies redirect cytotoxic $\mathrm{T}$ cells to cancer cells to form a cytolytic synapse followed by $\mathrm{T}$ cell activation, proliferation and cancer cell lysis. Besides blinatumomab, several bispecific antibodies engaging $\mathrm{T}$ cells show promising anti-cancer efficacy in clinical trials [7,8]. Moreover, targeting innate immune system by bispecific antibodies is another attractive strategy which has been gaining more and more interest. As an important member of innate immune system, nature killer (NK) cells play a major role in antibody dependent cytotoxic activity (ADCC) through FcyIIIA receptor (CD16A). So far, lots of excellent work has been made to enhance the effector function of therapeutic $\mathrm{mAb}$ by $\mathrm{Fc}$ mutation or glycosylation engineering. Bispecific antibodies are much more straightforward to bridge NK cells to cancer cells via CD16A receptor and clinical studies show that NK cell engager indeed demonstrates potent cancer killing effect [9]. As a bispecific fusion protein targeting NKG2D showing potent efficacy against human multiple myeloma, NKG2D could be an ideal target for bispecific antibodies to redirect and activate NK cells in cancer immunotherapy [10].
With the technological breakthrough in bioengineering, more and more novel platforms for bispecific antibodies are emerging. And the revival of bispecific antibodies gains the attention of biopharmaceutical companies. There is no doubt that bispecific antibodies will likely lead the antibody market in the next few years based on the encouraging clinical results in cancer immunotherapy.

\section{References}

1. Ramos P, Bentires-Alj M (2015) Mechanism-based cancer therapy: resistance to therapy, therapy for resistance. Oncogene 34: 3617-3626.

2. Koyama S, Akbay EA, Li YY, Herter-Sprie GS, Buczkowski KA, et al. (2016) Adaptive resistance to therapeutic PD-1 blockade is associated with upregulation of alternative immune checkpoints. Nat Commun 7: 10501.

3. Fitzgerald JB, Johnson BW, Baum J, Adams S, Iadevaia S, et al. (2014) MM-141, an IGF-IR- and ErbB3-directed bispecific antibody, overcomes network adaptations that limit activity of IGF-IR inhibitors. Mol Cancer Ther 2014: 13: 410-425.

4. Duman BB, Sahin B, Ergin M, Guvenc B (2012) Loss of CD20 antigen expression after rituximab therapy of CD20 positive B cell lymphoma (diffuse large B cell extranodal marginal zone lymphoma combination): a case report and review of the literature. Med Oncol 29: 1223-1226.

5. Foran JM, Norton AJ, Micallef IN, Taussig DC, Amess JA (2001) Loss of CD20 expression following treatment with rituximab (chimaeric monoclonal anti-CD20): a retrospective cohort analysis. Br J Haematol 114: 881-883.

6. Davis TA, Czerwinski DK, Levy R (1999) Therapy of B-cell lymphoma with anti-CD20 antibodies can result in the loss of CD20 antigen expression. Clin Cancer Res 5: 611-615.

7. Cioffi M, Dorado J, Baeuerle PA, Heeschen C (2012) EpCAM/CD3Bispecific T-cell engaging antibody MT110 eliminates primary human pancreatic cancer stem cells. Clin Cancer Res 18: 465-474.

8. Peng L, Oberst MD, Huang J, Brohawn P Morehouse C, et al. (2012) The CEA/CD3-bispecific antibody MEDI-565 (MT111) binds a nonlinear epitope in the full-length but not a short splice variant of CEA. PLoS One 7: e36412.

9. Rothe A, Sasse S, Topp MS, Eichenauer DA, Hummel H, et al. (2015) A phase 1 study of the bispecific anti-CD30/CD16A antibody construct AFM13 in patients with relapsed or refractory Hodgkin lymphoma. Blood 125: 4024-4031.

10. von Strandmann EP, Hansen HP, Reiners KS, Schnell R, Borchmann P, et al. (2006) A novel bispecific protein (ULBP2-BB4) targeting the NKG2D receptor on natural killer (NK) cells and CD138 activates NK cells and has potent antitumor activity against human multiple myeloma in vitro and in vivo. Blood 107: 1955-1962. 